$1-2016$

\title{
Place and Politics at the Frankfurt Paulskirche after 1945
}

Shelley Rose

Cleveland State University, shelley.rose@csuohio.edu

Follow this and additional works at: https://engagedscholarship.csuohio.edu/clhist_facpub

Part of the European History Commons

How does access to this work benefit you? Let us know!

Publisher's Statement

(c) 2016 SAGE Publications

\section{Repository Citation}

Rose, Shelley, "Place and Politics at the Frankfurt Paulskirche after 1945" (2016). History Faculty

Publications. 87.

https://engagedscholarship.csuohio.edu/clhist_facpub/87

This Article is brought to you for free and open access by the History Department at EngagedScholarship@CSU. It has been accepted for inclusion in History Faculty Publications by an authorized administrator of EngagedScholarship@CSU. For more information, please contact library.es@csuohio.edu. 


\title{
Place and Politics at the Frankfurt Paulskirche after 1945
}

\author{
Shelley E. Rose'
}

\begin{abstract}
This article investigates the reconstruction of the Frankfurt Paulskirche as a symbol of German democratic identity after World War II. The place memory of the Paulskirche is deeply rooted in the 1848 Parliament which anticipated the formation of a German democratic state. The church provided postwar Germans with a physical anchor for their sense of history and feelings of Heimat. This place identity pervades post-1945 debates about the reconstruction of the church and the appropriate uses of that space in the context of Frankfurt's devastated urban and political landscape. Despite this, the place identity of the Paulskirche remains understudied in the historiography. Rental agreements and correspondence reveal dynamic exchanges between city leaders, mainly members of the Social Democratic Party, and their constituents. Politicians, feminists, and peace activists all attempted to control the place identity of the Paulskirche after reconstruction, ultimately transcribing the space with additional political meaning.
\end{abstract}

\section{Keywords}

German History, Frankfurt, place, Paulskirche

In 1945, many Germans experienced a sense of placelessness. Bombed out city centers in Dresden, Hamburg, Berlin, and Frankfurt created a flattened German landscape void of the stability once fostered by meaningful cultural anchors in the built environment. Buildings like the Frankfurt Paulskirche embodied important foundations for the imagined German nation and, in particular, the liberal democratic promise of 1848 when politicians gathered in anticipation of the formation of a German nation-state: a goal only realized decades later. In the absence of familiar markers, postwar Germans found themselves with a powerful sense of place yet deprived of the landscape those feelings and memories once occupied. Frankfurt was a "world without history" (eine geschichtslose Erde) as the architect Max Frisch observed in 1946. ${ }^{1}$

Frisch illustrated the urban identity crisis in Frankfurt well. Indeed, historians Rudy Koshar, Peter Reichel and Thomas Bauer are among scholars who cite Frisch's vivid diary descriptions in their efforts to better understand the city's devastation. ${ }^{2}$ Frisch succinctly describes the human experience of the widespread urban destruction: "I can still imagine Munich, but no longer Frankfurt." 3 His dismay is a testament to geographer E.C. Relph's argument that national and local identities are closely tied to human interactions with specific spaces. ${ }^{4}$ In place of the Paulskirche, the famous site of the first German parliament in 1848, Frankfurt residents saw an

'Cleveland State University, Cleveland, OH, USA

\section{Corresponding Author:}

Shelley E. Rose, Department of History, Cleveland State University, 2 I 2 I Euclid Avenue, RT I326, Cleveland, OH 44II5-22I4, USA.

Email: shelley.rose@csuohio.edu 


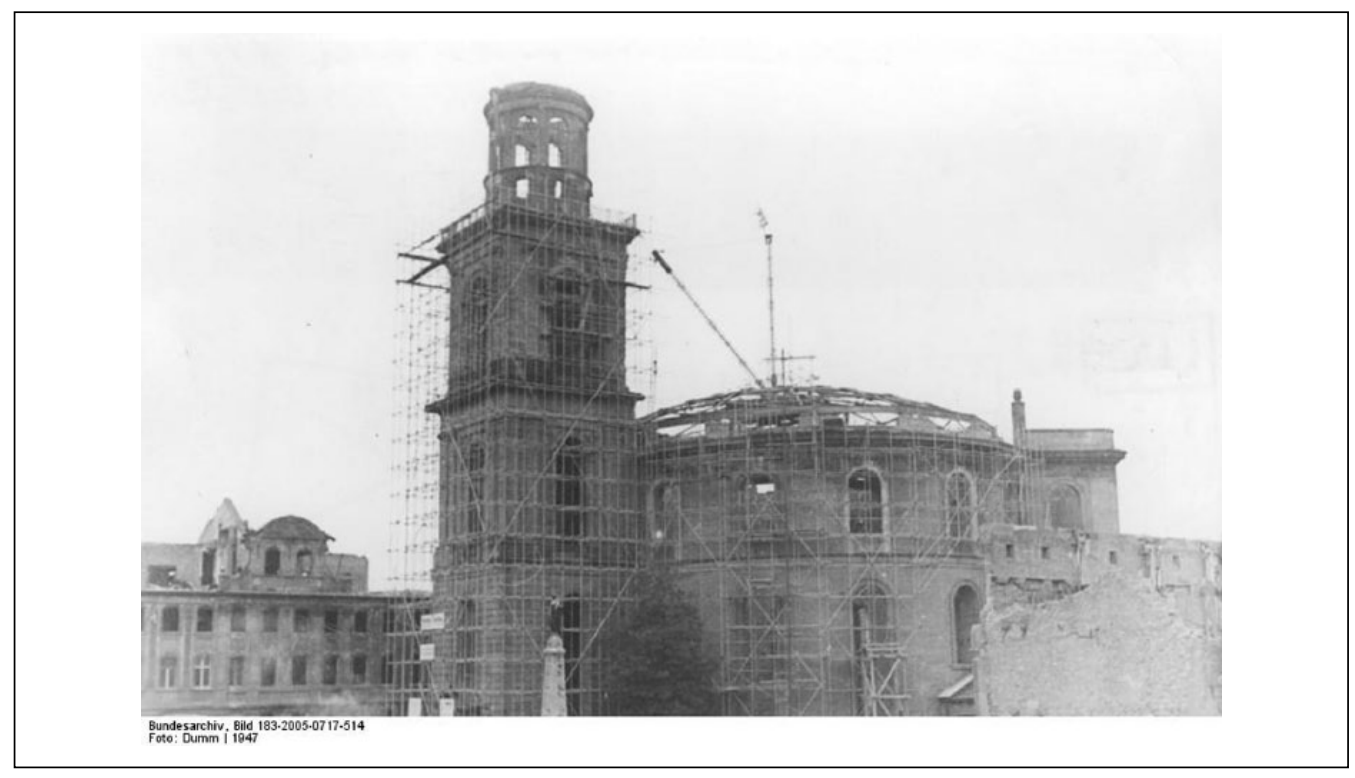

Figure I. Paulskirche, 1947.

Source: Bundesarchiv, Bild I83-2005-07I7-5I4 / photo: Dumm.

empty space marked by the characteristic round exterior walls of the church (Figure 1). This sense of placelessness in Frankfurt was even more disconcerting considering historian Peter Blickle's argument that the German idea of Heimat unites "geographic and imaginary conceptions of space" and "combines territorial claims with a fundamental ethical assurance of innocence." 5 According to Blickle, Heimat is intimately linked to geography and, as this analysis demonstrates, to geographical markers in the landscape such as the Paulskirche.

Scholars have traced the oldest human settlements in Frankfurt to around 2000 BCE. 6 Thousands of years of human interaction with the environment have shaped the city's urban landscape, including the structure of the old town (Altstadt); the "face" of the city according to architect Werner Hebebrand. ${ }^{7}$ Most of the old town was destroyed in Allied bomb attacks on March 18 and 22, 1944, and Germans yearned for traditional markers of a shared past. ${ }^{8}$ In particular, Frankfurt residents searched for cultural anchors in the flattened landscape that were not directly linked to the horrific actions of Nazi regime.

The composition of the Frankfurt postwar planning office alludes to the tensions over the city's identity and urban landscape. Hebebrand, Eugen Blanck and Herbert Boehm, three important city planners in postwar Frankfurt, were involved in Ernst May's interwar "New Frankfurt" program, which established standards for modern residential architecture and successfully provided housing for more than 10 percent of the city's population. May was a Frankfurt native and his Römerstadt settlement project completed between 1926 and 1932 reflected an effort to blend modern living with the natural environment. ${ }^{9}$ Blanck was elected to the Frankfurt city council in 1946 and appointed Hebebrand as the head city planner. Blanck and Hebebrand's presence effectively linked Frankfurt's lauded experiment in modern housing during the Weimar period to the city's postwar reconstruction. Most importantly, the architects' strong ties to the interwar "New Frankfurt" program overshadowed discussions about the recent Nazi past. ${ }^{10}$

In the absence of familiar geographic markers in the urban landscape, Frankfurt residents were compelled to reconstruct the old town. Relph briefly discusses the destruction of places during wartime as one of the "manifestations of placelessness" which "perpetuates uniformity 
and disorder" in the built environment. ${ }^{11}$ Koshar also recognizes this postwar placelessness in his examination of the connections between the built environment and memory, From Monuments to Traces: Artifacts of German Memory 1870-1990. Evaluating the aftermath of World War II, Koshar argues, "In both the Federal Republic and the Democratic Republic, the past was very much alive, if for no other reason than to give Germans a sense of orientation." 12 The need for a clear sense of place grounded in space, for Frankfurt residents and for Germans in general, pushed local leaders to rebuild the Paulskirche in the immediate aftermath of World War II.

Urbanist Dolores Hayden and American historian David Glassberg demonstrate powerful links between place identities, space, and political power in history. Hayden discusses the concept of "place memory" in her book The Power of Place. "It is the key to the power of historic places to help citizens define their public pasts," Hayden asserts. ${ }^{13}$ Indeed, historic sites like the Paulskirche inspire place memory in two ways. According to Hayden, "places trigger memories for insiders, who have shared a common past, and at the same time places often can represent shared pasts to outsiders." 14 In the placelessness of postwar Frankfurt, the Paulskirche represented a shared promise of liberal democracy in the German past to residents, or "insiders," and visually asserted German democratic will to "outsiders" such as American and British occupation authorities and the war-weary international community more broadly. As a historian, Glassberg explicitly links symbolic places to the shared past, arguing that the built environment provides individuals with a distinct "sense of history." 15 Glassberg's "sense of history" concept bridges the theoretical gap between humanist geographers and urbanists with professional historians who often take place for granted.

Place can be understood both as a physical location and an abstract political location. As Germans considered reconstruction after 1945, political leaders looked to the past for moments of promise in the face of great adversity: slices of time that resembled the physical and political topography of 1945. The physical reconstruction of the Paulskirche enabled Germans to resurrect the specific place memory of 1848 after World War II. Similarly, Social Democrats, who comprised one of the most vocal groups in this local postwar discussion of place memory, also eagerly anticipated a leading role in the political reconstruction of German democracy. As the sole party to vote against Hitler's Enabling Acts in 1933, Social Democratic leaders expected postwar recognition for their courage and hoped to garner enough voter support to become a majority party. ${ }^{16}$ Unfortunately for the Social Democrats, the party did not receive an overwhelming majority, and Social Democratic Party (SPD, Sozialdemokratische Partei Deutschlands) leaders opted for an official opposition position in the national political arena until 1966.

The SPD continued to enjoy a strong presence in postwar Frankfurt, however, and political leaders looked ahead to the promise of the city rising again not only as an economic stronghold but as a potential capital city in the Federal Republic of Germany. Indeed, historian Manfred Görtemaker cites "respect for the tradition of the Paulskirche" alongside Frankfurt's economic status among the main arguments for national support for Frankfurt's capital city bid. ${ }^{17}$ As a symbolic anchor of the united German past, prominent Social Democrats, like Frankfurt's first freely elected postwar mayor Walter Kolb, insisted the Paulskirche be rebuilt in time for the centennial of the 1848 Parliament even before practical political sites like the city hall, which was not completed until 1953. While the city hall (Römer) was a powerful local symbol, the place memory of the Paulskirche sparked the imagination of Germans on either side of the increasingly tense boundaries between East and West.

On January 20, 1947, Kolb issued a nationwide call to fund the Paulskirche reconstruction campaign. Kolb was not a Frankfurt native, but he understood the destruction of the church as part of the wider catastrophe of lost historic sites throughout Germany. The future mayor had already worried about the potential wartime destruction of the Heidelberg Castle in a 1924 article, revealing a sense of history deeply grounded in nationally significant locations. ${ }^{19}$ After his election in 1946, Kolb's urgent demands for reconstruction were also driven by the notion that 
the Paulskirche could become the future home of the German parliament. ${ }^{20}$ Indeed, Kolb's tenure as mayor and subsequent city debates about the use of the Paulskirche reveal increasing tensions between national political agendas and local reconstruction efforts.

Despite these efforts the German Parliamentary Council established Bonn as the provisional West German capital city on May 10, 1949, pushing Frankfurt to the margins of national politics. Lothar Kettenacker historicizes this decision well, arguing that the presence of Frankfurt's strong Social Democratic leadership helped persuade future Christian Democratic Chancellor Konrad Adenauer to lobby for Bonn. ${ }^{21}$ Furthermore, politicians objected to Frankfurt and the Paulskirche as the future site of the West German parliament on practical grounds. Liberal Democrat Theodor Heuss, who became the first West German president in 1949, claimed that the church "lacked the appropriate acoustic conditions for a parliament." 22 Even prominent Social Democrat Carlo Schmid expressed concerns about linking the postwar parliament site explicitly with the political goals of the 1848 Parliament through the space of the Paulskirche. ${ }^{23}$

The historiography surrounding the Paulskirche reflects Frankfurt's peripheral national political status: while scholars have diligently focused on the 1848 Parliament and the creation of subsequent national legends before 1933, there is a relative neglect of that place memory and its manipulation after the building's physical reconstruction in 1948. While some German memory scholars such as Brian Ladd argue cogently for the historical significance of place and repurposed spaces in the turbulent urban landscape of Berlin, they do not extend their focus to Frankfurt. ${ }^{24}$ Although the West German parliament did not end up occupying the space of the Paulskirche, the church retained its meaning as site of political transition and promise. In subsequent decades, rental contracts and city correspondence reveal that Frankfurt city officials both fiercely guarded this identity and political actors on the margins of the national political arena such as women, Social Democrats, and pacifists deftly manipulated the church's meaning for their own purposes.

The Paulskirche's national significance and place identity can be traced to the spring of 1848 . Members of the Frankfurt National Assembly rode the continental tide of revolution, meeting in the Frankfurt Paulskirche to draft a Charter of Basic Rights and a German Constitution. ${ }^{25}$ Though the 1848 revolution ultimately failed to establish a German democracy, many Germans identified this moment as a foreshadowing of successful unification less than three decades later. ${ }^{26}$ Indeed, historian Robert Gildea argues that diverse groups of Germans mobilized collective memories of 1848 to "legitimate themselves against the authoritarian empires that dominated Europe." 27 The Paulskirche, as the site of the Frankfurt National Assembly, became a site of political identity negotiation between formal and informal political actors. Mayor Kurt Blaum led the reconstruction efforts after World War II, which highlighted the Paulskirche as a symbol of German national unity untainted by the Nazi regime. Over the next twenty years, the Paulskirche became a stage for the manipulation, renegotiation, and construction of German political identities. ${ }^{28}$ Marginalized political actors such as women, pacifists, and antinuclear politicians fought for the right to occupy the space and place of the Paulskirche, reinforcing their own political legitimacy and potential.

Mayor Kolb recognized that the actions of the 1848 parliamentarians molded the physical space of the church into a vessel for political meaning and national rebirth in Frankfurt and beyond. The vessel of the Paulskirche did not inspire the same place memory in ruins, however. Relph asserts that a key aspect of place memory is "the special quality of insideness and the experience of being inside." ${ }^{29}$ Kolb emphasized the symbolism in the remaining "blocks of (local) Main red sandstone" but dismissed suggestions that the ruins of the Paulskirche provided an adequate background to the 1948 centennial celebrations, revealing tight connections between place and a sense of history. ${ }^{30}$ Kolb asserted, "[a] great people (Volk) not only provides shelter and bread for every single citizen: it also needs a house for itself!" 31 In order to fully reconstruct the place memory of the Paulskirche, Kolb appealed to every German for financial and material support, arguing, "All of Germany must rebuild the Paulskirche, from without and within, in stones and in spirit!" 32 
Donors across Germany answered Kolb's appeal for financial support, including contributors from cities that were as devastated as Frankfurt. In fact, the state government in Saxony donated 100,000 Reichsmarks. Potsdam, Brandenburg, and Erfurt also donated money to the cause and even the Zentralsekretariat of the East German Socialist Unity Party (SED; Sozialistischen Einheitspartei) in Berlin contributed 10,000 Reichsmarks - a testament to the Paulskirche's widespread status as a symbol of German national identity. ${ }^{33}$ Buoyed by this support, Kolb tirelessly pursued the Paulskirche reconstruction and successfully rededicated the building on the one-hundredth anniversary of the Frankfurt Assembly in 1948. ${ }^{34}$

The rededication certainly marked a new beginning for Frankfurt and the Paulskirche. Yet the question historian Charlene Mires poses in her study of Philadelphia's Independence Hall, "In a heterogeneous nation, whose legacy did Independence Hall represent?" rings true for the Paulskirche as well. ${ }^{35}$ Blanck predicted in 1947 that reconstruction of the Paulskirche meant that the Frankfurt old town would "again stand as a political and cultural centerpiece" of the city. ${ }^{36}$ With the church reconstruction complete, however, politicians and community members debated the symbolism of the church and questioned which organizations and events should occupy the space. Between 1948 and 1966, the struggle for control of the space and place identity of the Paulskirche provides a unique and underutilized analytical lens for studying political tension between actors on the margins of mainstream politics, the "penumbra" of politics as I have argued elsewhere, as well as mainstream national and local agendas. ${ }^{37}$

Rental agreements and correspondence surrounding the use of the Paulskirche after 1948 reveal the continuous renegotiation of political and national identities in the wake of Nazi atrocities as well as apprehension about communist influence and the specter of a divided Germany. City leaders feared that events with explicit political agendas would taint the image of national unity embodied in the church by transcribing additional or controversial meaning on the space. The 1948 rental conditions note that the city culture office and church officials shared custody of the space and declare that the Paulskirche could only be used in special circumstances during traditional Sunday worship service hours. ${ }^{38}$ They also paid homage to the place memory of the Paulskirche itself, stating that the church be available for events that "are served by the memory of the great past of the Paulskirche, particularly the expression of democratic will and meaning that transcends the location." Intriguingly, the conditions go on to explicitly prohibit the use of the church for events with "outspoken party-political or anti-church nature." 39 The authors of the rental conditions anticipated conflicts over the space of the Paulskirche and the need to control its use, but this policy often led to confusion when events embodied "democratic" will yet included participants whose party affiliations were expressly forbidden. Layers of place meaning in the space of the Paulskirche are evident here: originally as a Lutheran church and after 1848 as a site memorializing the potential of liberal democracy.

Frankfurt officials faced challenges regarding the use of the Paulskirche almost immediately. Several local newspapers addressed a practical complication associated with the newly constructed church. By diverting financial and material resources to the Paulskirche as one of the first reconstructed spaces in the city, Kolb effectively created the only venue in town that could accommodate large gatherings of approximately 1,000 people. Reacting to a 1951 social gathering held in the church by famous nutritionist Gayelord Hauser, one frustrated reporter from the Frankfurt Abendpost proclaimed, "the church has not been spared from events ranging from cabaret to postage stamp exhibits . . ." but "a cocktail party in the Paulskirche? Can it be true? What has happened to good taste?"40 Despite this criticism, Frankfurt officials struggled to maintain a balance between practical usage in a still devastated city and the image of the Paulskirche as a symbol of democracy. Most importantly, city leaders attempted to shield the church from partisan political use. A cocktail party might offend a German sense of history but it did not necessarily have the potential to erase or alter the political meaning of the place. 
Despite these debates, the postwar Paulskirche retained a place memory of political transition associated with the liberal democratic reformers who gathered there in 1848. Women were among the first groups to appropriate the Paulskirche for political—but not party political—purposes, drawing on the intent to foster "democratic will" addressed in the 1948 rental conditions. The 1948 Inter-Zone Women's Congress (Interzonalen Frauenkongress), 1951 Women's Peace Congress, and later, a 1957 antinuclear conference organized by local Hessian women all attempted to occupy this space to foster democratic awareness among women. ${ }^{41}$ Mayor Kolb personally welcomed the Inter-Zone Women's Congress to the church during the one-hundredth anniversary celebrations on May 22, 1948. Kolb invoked the spatial symbolism of the Paulskirche in the first sentences of his remarks, stating plainly that "the Paulskirche is the symbol of German democracy." 42 The mayor highlighted the hardships faced by German women in 1948 and drew direct parallels between their struggle for "equality, freedom, rights and social justice" and the 1848 Frankfurt Assembly. As he concluded, Kolb encouraged Congress attendees to reflect on the symbolic meaning of the physical space, "when you are gathered this afternoon in the ... Paulskirche, it will be with proud recognition of the great progress achieved by pioneers in the women's movement who fought ... for the same democratic ideals that the men of the Paulskirche grappled with one hundred years ago." 43 Frankfurt women's movement leader Helli Knoll pushed the connection further in her keynote speech, locating women not only in the 1948 historical moment but in the space of the 1848 Paulskirche as well. ${ }^{44}$

Knoll focused on the potential for German unity in 1948 and the continued presence of women as active companions to this democratic process. Knoll invoked the present space of the Paulskirche as a democratic place and emphasized the physical presence of women at the 1848 assembly as "spectators in a ladies gallery that was always overflowing" throughout the proceedings. ${ }^{45}$ Drawing attention to the presence of women in the galleries of the 1848 assembly served two purposes for Knoll. First, she illustrated that women were present at this founding moment of German democratic and national identity. The historical actors that gave the Paulskirche its national place meaning through their political actions included both men and women. Second, although women occupied space within the Paulskirche in 1848, they were physically limited to the margins of the venue and therefore this nationally significant political event (Figure 2).

The 1948 Women's Congress emphasized the transition of women from the physical margins of the Paulskirche, and the political margins of society, into the spotlight and the male-dominated political core. ${ }^{46}$ The space of the remodeled Paulskirche and its status as a former Lutheran church reinforced this political transition. Indeed, Paulskirche architect Rudolf Schwarz intended the reconstructed space to emphasize the spatial and emotional transition from "darkness and oppression into light and freedom. ${ }^{" 47}$ His postwar interior plan eliminated the balconies that were prominent in the 1848 interior and replaced the tiered seating with a flat central floor (Figure 3 ). The reconstructed church sanctuary maintained its round frame and speakers standing at the front podium stood practically level with the audience. This layout minimized the division between speaker and spectator and promoted a deeper sense of community. Building on this foundation, the Women's Congress leaders used the physical site of the Paulskirche to express their hopes that marginal spaces would cease to exist in the "light and freedom" Schwarz's layout emphasized in postwar German national political space.

Participants in the Women's Congress drew upon three main concepts associated with the space of the Paulskirche: national unity, equal political rights, and pacifism. Knoll connected these three ideals in her 1948 speech, addressing her last sentence to the Goethe Prize recipient and pacifist Fritz von Unruh and German women broadly as an appeal for "peace and understanding, sent from women at the Frankfurt Paulskirche to the women and mothers of the world." 48 Three years later, pacifist leader Klara Marie Fassbinder appealed again to German women from the floor of the Paulskirche, portraying the church as a space for the birth and rebirth of democratic agency. 


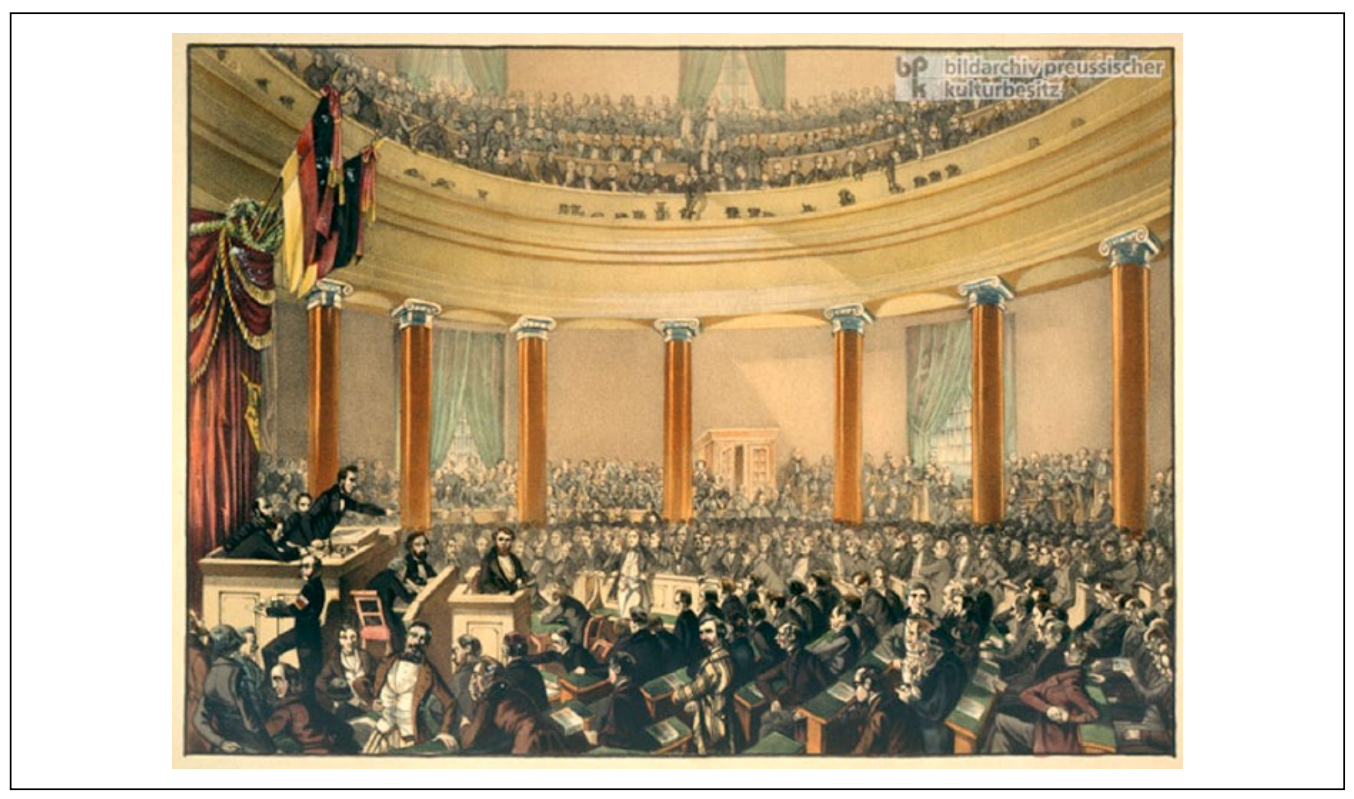

Figure 2. The National Assembly in the Frankfurt Paulskirche (Sitzung der Nationalversammlung in der Frankfurter Paulskirche, 1848).

Source: No. 00023092/bpk/ Dietmar Katz.

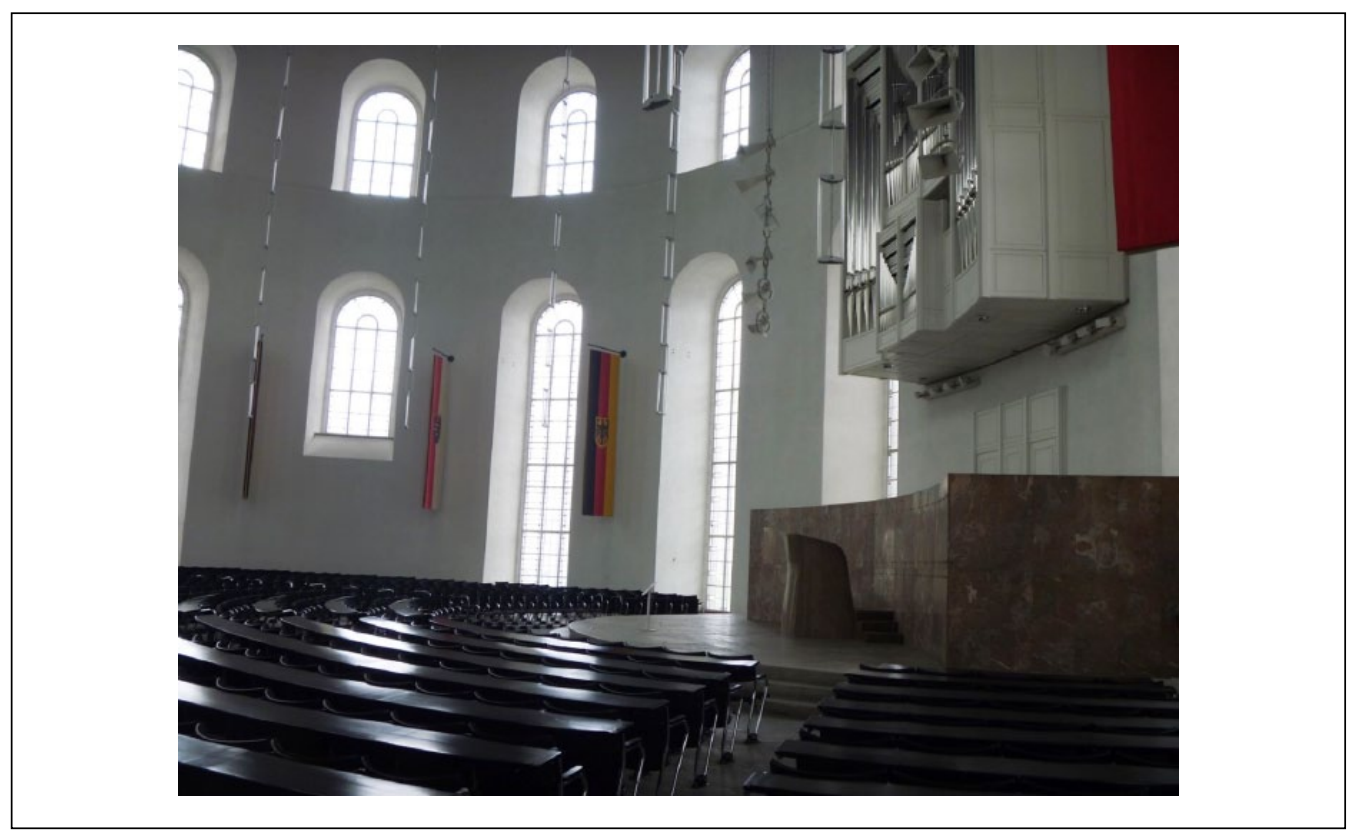

Figure 3. Paulskirche Interior, 2012.

Source: Photo by the author.

Pacifist organizers at the Women's Peace Congress held on January 13, 1951, including keynote speaker Fassbinder, drew connections between the postwar demonstration and the 1848 
democratic tradition of Germany's first national parliament. Fassbinder emphasized the presence of the Women's Peace Congress in the Paulskirche as a place where apolitical women could become political. These women's movement and pacifist leaders imagined the church not only as a site that reinforced the democratic legitimacy of the Congress, but as a transitional site for individual German women to move from political neutrality, or ambivalence, to activism. ${ }^{49} \mathrm{As}$ debates over the use of the Paulskirche space increased throughout 1951, organizers of the 1952 Women's Peace Congress found themselves denied access to the church. The dialogue between Congress planner Kaethe Klare-Kickhefel, a Frankfurt resident, and the culture office over the rental conditions is quite revealing. Kickhefel stressed that the group received no specific support from the "east" and that the participants acted in Christian faith. ${ }^{50}$ After much debate, Frankfurt officials conceded that the congress was not affiliated with a political party. City church officials had not rejected the application and the organizers denied connections to communist organizations; therefore, city leaders could not prohibit the women from the Paulskirche. This incident captures the three major perceived threats to the identity of the Paulskirche as a site of national unity and democratic will in the early 1950s: party-political affiliation, anti-church sentiment, and the threat of communist influence from East Germany.

Taking their cues from the women's and peace congresses, extraparliamentary (außerparlamentarische) peace activists repeatedly used the Frankfurt Paulskirche for demonstrations in the 1950s as well, drawing on the building's implicit and explicit meaning to demand political legitimacy from outside formal party politics. The organizers continued to emphasize their extraparliamentary political identities, however, to avoid outright prohibition from Frankfurt city officials according to the rental agreement. By 1948, it was clear to Social Democratic leaders that they would not reclaim the political majority and instead occupy opposition political space in the Federal Republic. In 1955, SPD chairman Erich Ollenhauer collaborated with extraparliamentary activists, journalists, clergymen, and academics to protest nuclear policies that they deemed destructive to German reunification. Known as the Paulskirche Movement (Paulskirche Bewegung), participants insisted that the 1955 demonstration was nonpartisan even though Ollenhauer's visible involvement blurred the lines between the formal political realm and informal, penumbra politics.

During the Paulskirche rally, pacifists, politicians, and unionists spoke out together against rearmament and in favor of reunification, all the while emphasizing their participation as independent of any political affiliation. ${ }^{51}$ Attended by one thousand participants, the demonstration enjoyed great support from individual Social Democrats. Many signers of the resulting "Deutsches Manifest" ranged from rank-and-file members to prominent Social Democrats like Herbert Wehner, Max Brauer, and Fritz Heine. ${ }^{52}$ Their participation, as well as Ollenhauer's, reinforced the SPD's emphasis on peaceful German reunification at the Paulskirche and emphasized the party's opposition and marginal position in the space of party politics. [Figure 4]

As this flyer illustrates, Paulskirche Movement participants mimicked Knoll and Kolb, drawing explicit connections between 1848 and their postwar vision for political transition. Sociologist Alfred Weber opened the 1955 rally with the statement "[w]e are gathered here in the Paulskirche, well-known for the much-criticized [vielverlaesterte] German Parliament that met here to take Germany's political unification to task." ${ }_{53}$ Weber imagined the potential for the 1955 Paulskirche rally as a meaningful foundation for reunification just as the 1848 assembly laid the foundations for unification. Journalist Georg Reuter took the podium directly after Weber, drawing yet another connection between the gathering of "free and independent public figures" and the "memorable location" of the rally. ${ }^{54}$

The organizers attempted to manipulate the physical space of the Paulskirche as a reflection of egalitarian representation within their own movement and in national politics. As demonstrated by the 1948 Women's Congress, the spatial intimacy of the postwar interior provided politicians with the symbolic tools to transcend party political boundaries. SPD leaders like party 


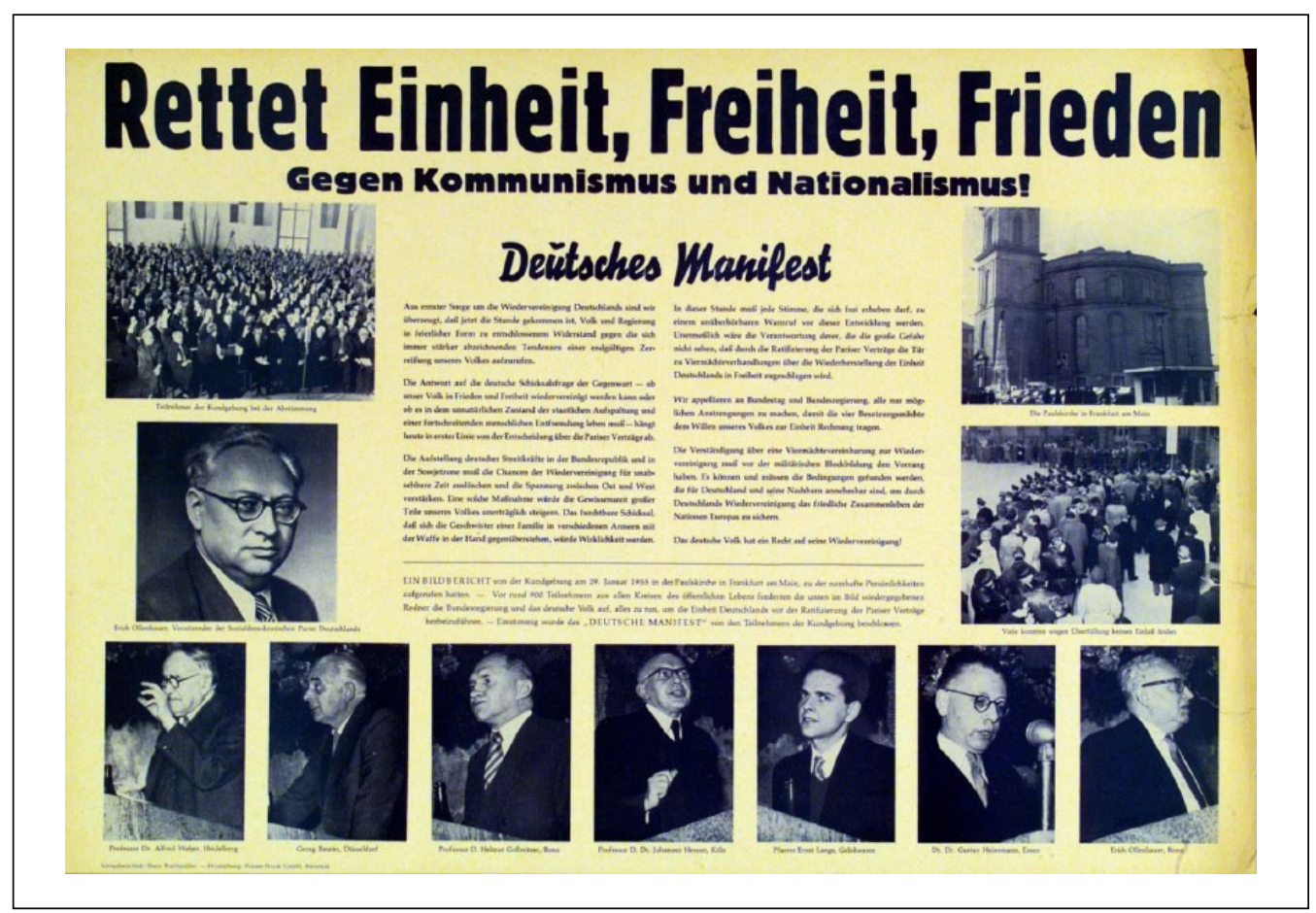

Figure 4. Paulskirche Movement Flyer, "Rescue Unity, Freedom, and Peace!” (“Rettet Einheit, Freiheit und Frieden!"), 1955.

Source: Courtesy of the Archiv der sozialen Demokratie der Friedrich-Ebert-Stiftung Bonn.

chairman Erich Ollenhauer mingled with grassroots extraparliamentary activists on the church floor, at the same time pressing a formal political agenda from the physical margins of Frankfurt and the political margins of opposition. ${ }^{55}$

The 1955 program concluded with two politicians from opposition parties. Gustav Heinemann from the All German People's Party (GVP, Gesamtdeutsche Volkspartei), who later joined the SPD, emphasized the call for reunification and advocated individual political responsibility. "The citizen who remains inactive must endure what has been dictated for him," the politician cautioned, urging Germans to see the Paulskirche as a site of political transition and rebirth as Fassbinder had four years earlier. ${ }^{56}$ Ollenhauer spoke next, connecting issues of reunification and peace to the party arena then dominated by the Christian Democratic Union (CDU, Christlich Demokratische Union Deutschlands). Drawing on the symbolic space of the Paulskirche, Ollenhauer consistently used the place identity of the church as a site of democratic promise and transition to promote solidarity among demonstrators that transcended political, confessional, and generational boundaries. ${ }^{57}$

One striking aspect of the 1955 Paulskirche rally was the absence of women from the roster of speakers. As opposed to the Women's Congresses and the later SPD-sponsored "Campaign against Atomic Death" (KdA, Kampf dem Atomtod) movement and the extraparliamentary Easter Marches, the Paulskirche Movement was dominated by men. ${ }^{58}$ This is particularly surprising in the space of the Paulskirche, since activists like Knoll and Fassbinder had already infused the church with political meaning as a site where apolitical women could become political. Indeed, SPD and GVP leaders framed the Paulskirche appeal carefully, using an all-male cast to front their critique of mainstream "masculine" politics. As Gail Bederman demonstrates for 
American politics, “electoral politics dramatized and reinforced men's connection, as men, to the very real power of government." 59 Perhaps Ollenhauer and his co-organizers felt their political critique would be weaker if they included female voices in the Paulskirche Movement. The increasing presence of women in party politics led to heightened gender tension in the changing political landscape of postwar West Germany. For example, Social Democratic MdB Lucie (Kurlbaum) Beyer co-organized a July 7, 1957, women's conference supported by the Combat Group against Nuclear Destruction (Kampfbund gegen Atomschäden) yet showcased male MdB Karl Bechert as the keynote speaker. ${ }^{60}$

In order to gain access to the Paulskirche, Beyer and her colleagues stressed the nonpartisan nature of the rally, going so far as listing twenty-eight individual women as the sponsors of the event rather than any single organization. ${ }^{61}$ Yet by staging the rally at the Paulskirche, organizers stressed the political nature of engaged scientists like Nobel Prize-winner and outspoken pacifist Albert Schweitzer and drew attention to the antinuclear cause. Taking cues from International Women's Day efforts to highlight the dangers of atomic weapons as a major concern for postwar women, the conference was "nonpartisan and non-denominational" and addressed the theme "What are tasks for women and mothers in the atomic age?" 62 As a testament to the solidarity among "women and mothers" against atomic weapons, participants in the women's conference issued a statement outlining their position and called especially for the West German government to support a nuclear-free zone in central Europe. Fassbinder considered the movement a success. In accordance with her goals for the 1951 Women's Congress, the 1957 event inspired eighteen women's organizations to adopt a resolution on the nuclear issue. ${ }^{63}$ To Fassbinder, these eighteen organizations represented women who were previously unconnected to politics who became politically active through the use of the Paulskirche as transitional space.

Over the next two years, antinuclear organizations repeatedly sought access to the Paulskirche venue to demonstrate political influence and solidarity among peace activists. With the Paulskirche Movement, political leaders, especially from the SPD, ventured from masculine party political space into the extraparliamentary realm often characterized as feminine, seeking to capitalize on growing grassroots support for antinuclear protests. Party efforts to influence antinuclear politics from the political penumbra culminated in the organization of the Campaign against Atomic Death (i.e., KdA) movement in 1958. With this new effort, the SPD openly straddled party politics and extraparliamentary activism, positioning itself between core and penumbra in the political arena and blurring gendered notions of peace and political space. Not coincidentally, party leaders chose the Paulskirche as a primary venue for the KdA, building on the site's symbolism as a place of political transition, a platform for liberal democracy, and nonpartisan cooperation in the postwar years. A year later, KdA members participated in the transnational European Congress for Nuclear Disarmament on January 17 and 18, 1959. The Congress began in London and concluded with a ceremony at the Frankfurt Paulskirche hosted by the local Social Democratic government, reinforcing the Paulskirche's symbolic value for both national and transnational peace demonstrations. ${ }^{64}$

Correspondence among the organizers for the European Congress for Nuclear Disarmament shed light on an interesting new dynamic surrounding the use of the Paulskirche. In one of the only incidences in Frankfurt city records, Mayor Werner Bockelmann, a member of the SPD, proactively offered the use of the Paulskirche to the Germany-based Committee against Nuclear Armament (Komitee gegen Atomrüstung). Original plans to hold the transnational antinuclear congress in Switzerland fell through when the Swiss government banned the event. The primary speakers, in particular British activist Bertrand Russell, could not travel to Germany, causing further complications. ${ }^{65}$ As plans solidified for a primary congress venue closer to Russell in London, Bockelmann suggested that the congress itself cross national borders, beginning in London and traveling to Germany for a closing rally in the Paulskirche. ${ }^{66}$ Although Bockelmann addressed congress delegates in the City Hall, physically separating his political position as 
Social Democrat and mayor from the Paulskirche, the main event titled "Europe Calls" was held in the Paulskirche, linking directly to the democratic symbolism of the site and invoking a broader European image of the 1848 democratic revolutions in support of this emerging European antinuclear organization. ${ }^{67}$

Between 1955 and 1959, extraparliamentary activists and politicians manipulated the rental conditions of the church and its symbolism to fit their own goals. Indeed, Bockelmann answered critics who questioned whether he was a "mayor or party politician" with the assertion that his participation in the SPD-sponsored KdA, and the organization itself, focused on the issue of nuclear weapons as a national, European, and world problem. ${ }^{68}$ Bockelmann, like Kolb and Blaum before him, was not originally from Frankfurt, prompting local residents to question his political loyalty and, by extension, his stewardship of the Paulskirche as a local landmark.

Hans-Konrad and Helga Tempel, founders of the German Easter March Movement in 1960, also protested the use of nuclear weapons in Germany and abroad. The Tempels drew inspiration for the German Easter marches from the British marches to Aldermaston and sought to rekindle support for antinuclear extraparliamentary activism in Germany. ${ }^{69}$ Cooperation between Social Democratic leaders and extraparliamentary peace activists dwindled in the 1960s due to an SPD ban on the Easter Marches. Nevertheless, Easter March organizers drew upon the place identity of the Paulskirche, both the 1848 symbolism and the repeated use of the space after reconstruction by marginal political organizations, to advance their own political agenda.

In 1963, Hessen Easter March organizers deftly manipulated the Paulskirche's symbolic political capital and identity as a transitional space. An article in Die Andere Zeitung declared "it has been five years since Erich Ollenhauer announced 'We will not rest so long as our people are threatened by nuclear death." 70 Yet, the anonymous author argues, the SPD-sponsored KdA campaign had long been abandoned by SPD leaders and the nuclear threat still existed. Five years after the 1958 rallies, Hans-Konrad Tempel declared from the Paulskirche, "where Erich Ollenhauer once stood," that "[Easter Marchers were] going to the streets because those who should represent us do not represent us anymore."71 By invoking the image of the SPD chairman, Tempel recognized the place memory of the Paulskirche and the political meaning transcribed on the space by the 1950s movements held in the church. Furthermore, the tenuous relationship between SPD party politics and extraparliamentary movements after 1960 created new national political space, laying the symbolic foundations for the Easter Marches and prompting Die Andere Zeitung to declare in 1963 that the Marches were the "legitimate successors" of the KdA and its political influence.

The 1963 Easter March rally in Frankfurt signaled a new era in the place history of the Paulskirche. While the site remained a place of political transition, Tempel not only invoked the 1848 democratic legacy of the Paulskirche, he called upon a more recent memory: the use of the space by party political actors, in particular SPD chairman Erich Ollenhauer, in the 1950s. For Frankfurt city leaders this meant two infractions on the rental conditions for the Paulskirche. First, city regulations had failed to protect the place identity of the church as a pure site of national democratic promise and, second, an extraparliamentary organization alleged to have communist influences drew attention to this failure using the church's inherent symbolism of political potential to enhance their own agenda.

The long-term ramifications of the 1963 Easter March rally can be seen in the subsequent conflicts between activists and city officials bent on censoring the use of the Paulskirche. While Helli Knoll and Aenne Kolb, Walter Kolb's widow, were able to use the Paulskirche rent-free to host a nonpartisan commemoration of Nobel Peace Prize winner Bertha von Suttner's death in 1964, Easter March leaders were confronted with official restrictions and criticism of their activities. ${ }^{72}$ Concerned citizens and organizations corresponded with the city government, complaining that the Easter Marchers would misuse the "symbol of democracy" and utilize the space for communist purposes. ${ }^{73}$ The local Hessian Easter March group nonetheless succeeded in 
procuring the Paulskirche for a rally "Against the Proliferation of Atomic Weapons-for a Nuclear Weapon Free Zone in Central Europe" as late as March 20, 1965. Significantly, city correspondence shows this event to be the first recorded instance where officials imposed additional conditions on their use, including the preapproval of speakers. ${ }^{74}$ By September 1965, local Easter March leader Klaus Vack received a letter from Mayor Brundert distinguishing between the character of two Easter March events: a September 1 "Anti-War Day" was allowed to take place because of its "general political character" but an Anti-Vietnam rally planned for the same month was forbidden. ${ }^{75}$ Brundert concluded with the following statement: any "appeal against this decision will fail because no one, neither an individual nor an organization, is entitled to the Paulskirche." 76 This exchange reveals city leaders' ongoing struggle to justify restricted access to the Paulskirche and their fierce defense of its nationally significant place identity.

In 1966, municipal leaders revised the Paulskirche rental agreement to include this statement:

Today the Paulskirche is widely considered a symbol of past democratic will in Germany and abroad and therefore has become one of our most meaningful political memorials. ... [I]n recognition of this meaning, it can only be made available for events which have the proper basic character. ${ }^{77}$

The rental agreement reinforced the necessity to preserve the Paulskirche's identity as a national democratic symbol and set the framework for the specific type of events allowed to use the space. The contract includes a very limited list of appropriate choices such as award ceremonies for the Goethe Prize, the Peace Prize of the German Book Exchange, the Paul-Ehrlich Prize, as well as ceremonies for official days of remembrance, holding them as examples of acceptable events against which all future requests should be compared. ${ }^{78}$ Extraparliamentary Easter March events banned by the Social Democratic Party and suspected of communist infiltration by party leaders did not correspond to these new benchmarks.

The increasing debates over proper use of the Paulskirche reveal important shifts in SPD policy. Frankfurt mayors Walter Kolb, Werner Bockelmann, and Willi Brundert were all SPD members. As such, Kolb and Bockelmann had been relatively lenient in the use of the Paulskirche by individual members of the SPD and, even in Bockelmann's case, actively offered the space in support of events that aligned with Social Democratic antinuclear politics. In 1960, however, the SPD banned its members from participating in the extraparliamentary Easter March movement, citing communist infiltration and encouraging members to pursue antinuclear politics within party ranks. ${ }^{79}$ City officials affiliated with the SPD controlled access to the space of the Paulskirche, and the church itself became a stage for the broader power struggle between the SPD and the extraparliamentary Easter Marches.

Local politicians controlled access to the interior of the Paulskirche, but the iconic round red sandstone walls remained a powerful marker of political transition and democratic change. As pacifists revived the Easter Marches in the 1980s, the iconic profile of the Paulskirche can be seen in the background of antinuclear rallies that spread from the square outside the church (Paulsplatz) to the nearby Römer. In 1982, Easter Marchers estimated over thirty thousand people gathered at the Paulsplatz, another fifty thousand in 1983, and in 1988 they estimated twentyfive thousand participants. ${ }^{80}$ Just as Erich Ollenhauer used the exterior of the church as a visual symbol of democratic promise and national unity in the 1955 Paulskirche Movement publicity (Figure 4), Easter March organizers in the 1980s embraced the Paulskirche's place identity to legitimize and position their own movement in the German political arena.

The Frankfurt Paulskirche serves as a potent reminder that space itself can embody political meaning and be used to ascribe additional symbolism to those individuals and organizations who occupy it. Frankfurt city officials recognized the potential of place memory at the Paulskirche: first in the immediate reconstruction of the church after World War II and second in their efforts 
to control access to the church. The use of the Paulskirche by women's organizations, pacifists, politicians, and extraparliamentary groups reveals that place memory is not easily policed. For example, the 1957 antinuclear rally for women worked around these guidelines, presenting a highly political event featuring known party politicians, yet arguing that the sponsors were simply a group of nonpartisan women. Extraparliamentary activists consistently worked within the frameworks of city-imposed regulations in order to access the powerful democratic symbolism of the Paulskirche. Easter March organizers in the 1980s continued to draw on the democratic identity of the Paulskirche even after the imposition of stricter regulations in 1966. For the Easter March activists, the space of the Paulskirche as a meaningful place extended to the public square in front of the church. The marchers could invoke the church's connection with political promise from the Paulsplatz because the image of the iconic church's exterior proved enough to facilitate the memory of German democratic will. Unfortunately for Frankfurt city officials, the exterior image of the church proved even more difficult to regulate, and both the interior and exterior of the building remain an important anchor for many German's sense of history to the present day.

\section{Author's Note}

This article would not have been possible without the advice and encouragement of J. Mark Souther. I also wish to thank Eric Limbach, Matias Martinez-Abeijon, Jean Quataert, Stewart Anderson, and the anonymous reviewers for the Journal of Urban History for their valuable comments.

\section{Declaration of Conflicting Interests}

The author declared no potential conflicts of interest with respect to the research, authorship, and/or publication of this article.

\section{Funding}

The author disclosed receipt of the following financial support for the research, authorship, and/or publication of this article: The author received research support from Cleveland State University for this article.

\section{Notes}

1. Max Frisch, Tagebuch 1946-1949 (Frankfurt am Main: Suhrkamp Verlag, 1950), 38. See Dieter Langewiesche, "Revolution in Germany: Constitutional State-Nation State- Social Reform," in Europe in 1848: Revolution and Reform, ed. Dieter Dowe et al. (New York: Berghahn Books, 2001), 120-42, for a discussion of the 1848 Revolution as an attempt to establish the German nation-state.

2. See Rudy Koshar, From Monuments to Traces: Artifacts of German Memory, 1870-1990 (Berkeley: University of California Press, 2000), 155; Peter Reichel, Politik mit der Erinnerung: Gedächtnisorte im Streit um die nationalsozialistische Vergangenheit (Munich: Carl Hanser Verlag, 1995), 72; Thomas Bauer, "Seid einig für unsere Stadt:" Walter Kolb, Frankfurter Oberbürgermeister 1946-1956 (Frankfurt am Main: Waldemar Kramer, 1996), 31. Hereafter cited as Bauer, Kolb.

3. Frisch, Tagebuch, 37.

4. E.C. Relph, Place and Placelessness (London: Pion, 1976), 143-47.

5. Peter Blickle, Heimat: A Critical Theory of the German Idea of Homeland (New York: Camden House, 2002), 1. Celia Applegate discusses the relationship between Heimat and place generally in her seminal work A Nation of Provincials: The German Idea of Heimat (Berkeley: University of California Press, 1990).

6. Werner Durth and Niels Gutschow, Träume in Trümmern. Planungen zum Wiederaufbau zerstörter Städte im Westen Deutschlands, 1940-1950 (Braunschweig/Weisbaden: Friedr. Vieweg \& Sohn, 1988), 465.

7. Ibid., 477.

8. Evelyn Hils-Brockhoff and Sabine Hock, Die Paulskirche: Symbol Demokratischer Freiheit und nationaler Einheit (Frankfurt am Main: Institut für Stadtgeschichte, 2004), 71.

9. Susan R. Henderson, "Römerstadt: the Modern Garden City," Planning Perspectives 25, no. 3 (July 2010): 323-24. 
10. Durth and Gutschow, Träume, 476-77. Though Hebebrand worked as a city planner during the Nazi period, Jeffrey Diefendorf explores the widespread occurrence of prominent postwar architects who worked on city reconstruction during World War II. He concludes that while these architects applied their planning concepts during the Nazi Regime, they viewed their work as apolitical. Indeed, Hebebrand faced postwar criticism primarily for his modernist ideas. See Diefendorf, In the Wake of War: The Reconstruction of German Cities after World War II (New York: Oxford University Press, 1993), 187-88.

11. Relph, Place and Placelessness, 109. See especially note 11 where Relph discusses the scholarly neglect of wartime destruction as influential to place identity. This is even more potent since it appears as a footnote to Relph's primary analysis.

12. Koshar, Monuments to Traces, 150-51.

13. Dolores Hayden, The Power of Place: Urban Landscapes as Public History (Cambridge: MIT Press, 1995), 46.

14. Ibid., 46.

15. David Glassberg, Sense of History: The Place of the Past in American Life (Amherst: University of Massachusetts Press, 2001), 6. Glassberg defines a "sense of history" as "a perspective on the past at the core of who they are and the people and places they care about," and that "sense of history reflects the intersection of the intimate and the historical."

16. Heinrich Potthoff and Susanne Miller, Kleine Geschichte der SPD: 1848-2002 (Bonn: Dietz, 2002), 190-91.

17. Manfred Görtemaker, Geschichte Der Bundesrepublik Deutschland (Munich: C.H. Beck, 1999), 60.

18. Hartwig Beseler, Niels Gutschow, and Frauke Kretschmer, Kriegsschicksale: deutscher Architektur : Verluste, Schäden, Wiederaufbau : eine Dokumentation für das Gebiet der Bundesrepublik Deutschland (Neumünster: K. Wachholtz, 1988), Vol. 2, 811.

19. Hilmar Hoffmann, Frankfurts Oberbürgermeister 1945-1995 (Frankfurt: Societäts-Verlag, 2012), $84-85$.

20. Bauer, Kolb, 40.

21. Lothar Kettenacker, Germany since 1945 (Oxford: Oxford University Press, 1997), 40.

22. Durth and Gutschow, Träume, 502.

23. Reiner Pommerin, Von Berlin nach Bonn: Die Allierten, die Deutschen und die Hauptstadtfrage nach 1945 (Köln: Böhlau Verlag, 1989), 92.

24. Brian Ladd, The Ghosts of Berlin Confronting German History in the Urban Landscape (Chicago: University of Chicago Press, 1998). See also Diefendorf, In the Wake of War. Diefendorf's expansive study of postwar reconstruction discusses Frankfurt in the context of broader debates on reconstruction and the Paulskirche on pages 76-78. Rudy Koshar also discusses the Paulskirche briefly in From Monuments to Traces. Notably, Susanne Vees-Gulani includes the Goethehaus in her analysis: VeesGulani, "From Frankfurt's Goethehaus to Dresden's Frauenkirche: Architecture, German Identity, and Historical Memory after 1945," The Germanic Review 80 (2005): 143-63.

25. Jonathan Sperber, The European Revolutions 1848-1851 (Cambridge: Cambridge University Press, 1994), 128-29.

26. See Tim Klein, ed., 1848. Der Vorkampf deutscher Einheit und Freiheit: Erinnerungen, Urkunden, Berichte, Briefe (Ebenhausen-Munich: Langewiesche-Brandt, 1914).

27. Robert Gildea, "1848 in European Collective Memory," in Dowe, Europe in 1848, 934-35.

28. For my understanding of the Paulskirche as a "public stage for enacting beliefs and ideas about the past," see Charlene Mires, Independence Hall in American Memory (Philadelphia: University of Pennsylvania Press, 2002), Introduction.

29. Relph, Place and Placelessness, 141.

30. Walter Kolb, “Aufruf der Stadt Frankfurt am Main zum Wiederaufbau der Paulskirche," January 20, 1947. Signatur: Ffm Kq 6/746, Goetheuniversitätsbibliothek, Frankfurt am Main.

31. Ibid.

32. Ibid.

33. Durth and Gutschow, Träume, 484. Potsdam donated 10,000 RM, Erfurt 5,000 RM, and Brandenburg 5,000 RM. Other donations included supplies from various municipal and state governments. Durth and Gutshow argue that these donations from Soviet-occupied Germany reflect hopes for unification. 
34. Hils-Brockhoff and Hock, Die Paulskirche, 71.

35. Mires, Independence Hall, 116.

36. Blanck, Eugen "Gedanken zum Wiederaufbau Frankfurts," October 15, 1947, in Durth and Gutschow, Träume, 522.

37. The core/penumbra model is drawn from the ideas of French historians, in particular Colin Jones and Laurence Brockliss. According to the Jones and Brockliss model, the medical world of early modern France consisted of two main spheres, the institutional core and groups in the penumbra surrounding it. The authors emphasize permeability and exchange between the core and marginalized participants as a key aspect of the term "penumbra." I apply this model to German political space in my research: formal party politics form the institutional core and informal political actors occupy the penumbra. See Brockliss and Jones, The Medical World of Early Modern France (New York: Clarendon Press, 1997), Introduction.

38. "Bestimmungen für die Überlassung der Paulskirche zu Tagungen und ähnlichen Veranstaltungen an Dritte" (November 5, 1948), Blatt 6, Signatur 4.460, Magistratsakten, ISG, Frankfurt am Main.

39. Ibid.

40. “Cocktail -Party jetzt sogar in the Paulskirche?" Abendpost, October 3, 1951.

41. The city of Frankfurt is located in the German state (Land) of Hesse. The 1957 conference was organized by women from across the state.

42. Walter Kolb, "zur Begrüssung der Frauen, die zum interzonalen Frauenkongress am 22. Mai 1948 nach Frankfurt gekommen sind," 1. S3-T 5549, Sammlung S3 “Ortsgeschichte,” ISG, Frankfurt am Main.

43. Ibid., 3 .

44. Helli Knoll, "Festvortag von Frau Helli Knoll in der Frankfurter Paulskirche zum Interzonale Frauenkongress am 22. Mai 1948," 1. S3-T 5549, Sammlung S3 “Ortsgeschichte," ISG, Frankfurt am Main.

45. Ibid. Historian Gabriella Hauch confirms the presence of women in the Paulskirche spectator's gallery in her article "Women's Spaces in the Men's Revolution of 1848" in Dowe, Europe in 1848, 639.

46. Applied to political space, my core and penumbra political framework draws on the observations of Paula Baker and Gail Bederman that party politics represents a traditionally masculine realm. Gail Bederman, Manliness and Civilization: A Cultural History of Gender and Race in the United States, 1880-1917 (Chicago: University of Chicago Press, 1995). Paula Baker, The Moral Frameworks of Public Life: Gender Politics and the State in Rural New York, 1870-1930 (Oxford: Oxford University Press, 1991).

47. Hils-Brockhoff and Hock, Die Paulskirche, 72.

48. Knoll, "Festvortrag," 8.

49. Gisela Notz, "Klara Marie Fassbinder" Journal of Women's History 13 (2001), 104. Hereafter cited as Notz, "Fassbinder."

50. Letter from Klare Kaethe Kickhefel to Oberbürgermeister Walter Kolb, November 29, 1951. Blatt 66, Signatur 4.461, Magistratsakten 47/49, ISG, Frankfurt am Main. See also "Frauen Friedenskongress," Blatt 78, Signatur 4.461, Magistratsakten 47/49, ISG, Frankfurt am Main.

51. Görtemaker, Geschichte der Bundesrepublik Deutschland, 328. "Rettet Einheit, Freiheit, Frieden! Gegen Kommunismus und Nationalismus!" Paulskirche Demonstration on January 29, 1955 (Frankfurt am Main: Union Druckerei, 1955). Peace historian Eckart Dietzfelbinger cites the Paulskirche movement as the first time that the SPD, GVP, and penumbra organizations worked together in a nonpartisan protest movement. Die Westdeutsche Friedensbewegung 1948 Bis 1955: Die Protestaktionen Gegen Die Remilitarisierung Der Bundesrepublik Deutschland (Cologne: Pahl-Rugenstein, 1984), 186.

52. See "Rettet Einheit, Freiheit, Frieden! Gegen Kommunismus und Nationalismus!" (Pamphlet). The Paulskirche crowd was not the only audience for this new political cooperation; the speeches were broadcast on the radio and printed in pamphlets containing the full text as well as copies of the "Deutsches Manifest." Hans Karl Rupp, Außerparlamentarische Opposition in der Ära Adenauer der Kampf Gegen die Atombewaffnung in den Fünfziger Jahren: Eine Studie zur Innenpolitischen Entwicklung der BRD (Cologne Pahl-Rugenstein, 1984), 50.

53. "Rettet Einheit, Freiheit, Frieden! Gegen Kommunismus und Nationalismus!" (Pamphlet), 2.

54. Ibid., 4.

55. Ibid., 78 . 
56. Ibid., 10 .

57. Ibid., 12.

58. "Rettet Einheit, Freiheit, Frieden! Gegen Kommunismus und Nationalismus!"(Pamphlet), 13-16. A total of 206 people signed the Paulskirche Manifest, only seventeen (8\%) of whom were women. Most of these seventeen women were Social Democrats, and the statistics correspond with the growing, but limited, direct participation of women in West German politics during the 1950s. Therefore, $8 \%$ of Paulskirche signees were female compared with 7\% female MdBs (MPs) in 1949 and a 1950s high of 9.6\% for female Social Democratic representatives within their own party. Gisela Notz, Frauen in der Mannschaft:Sozialdemokratinnen im Parlamentarische Rat und im Deutschen Bundestag 1948/1949 bis 1957 (Bonn: Dietz, 2003), 36, 50.

59. Bederman, Manliness and Civilization, 13.

60. Notz, "Fassbinder," 115. MbB stands for Member of Parliament (Mitglied der Bundestag).

61. Flugblatt, "Gegen die Atomgefahr," July 7, 1957. Signatur 2.420, Magistratsakten III/2-1979, ISG, Frankfurt am Main. This emphasis on individuals was reinforced by Mayor Bockelmann's inter-office memo on the subject in the same file: Letter from Bockelmann to Frau Dr. Elisabeth Schwarzhaupt, July 5, 1957. Signatur 2.420, Magistratsakten III/2-1979, ISG, Frankfurt am Main.

62. Poster "Gegen die Atomgefahr," July 7, 1957. Signature 613/84, NL Kloppenburg, EZAB. See Karl A. Otto, Vom Ostermarsch zur APO: Geschichte der Ausserparlamentarische Opposition in der Bundesrepublik 1960-1970 (Frankfurt am Main: Campus-Verlag, 1977), 56, and Rupp, Außerparlamentarishe Opposition, 70, for background on the Kampfbund Gegen Atomschäden, which Bechert co-founded in 1956. For more on the women's conference, see Peter Brollik and Klaus Mannhardt, Blaubuch 1958: Kampf dem Atomtod und Aufrufe (Essen: Klartext, 1988), 213.

63. Notz, "Klara Marie Fassbinder," 115.

64. Protokoll der Sitzung des zentralen Ausschusses "Kampf dem Atomtod," February 21, 1959, Mappe 286, Folder 7, NL Helene Wessel, AdsD, Bonn.

65. Bulletin "Campaign for Nuclear Disarmament-European Congress for London," November 1958.

66. Letter from Bockelmann to Hajo Schedlich, November 14, 1958. Signature 2.420, Magistratsakten III/2-1979, ISG, Frankfurt am Main.

67. Invitation and Program “Europäischer Kongress Gegen Atomrüstung," January 17-18, 1959. Signature 2.420, Magistratsakten III/2-1979, ISG, Frankfurt am Main.

68. "Das Offene Geheimnis 'Oberbürgermeister oder Parteipolitiker?'” Mitteilungen der Stadtverwaltung Frankfurt A-M, June 21, 1958. Heft 1958, S2/61A, Personnengeschichte Werner Bockelmann, ISG, Frankfurt am Main.

69. Johannes Bastian, "Ein Blick in die Geschichte der Friedensbewegung," Westermanns Pädogogische Beiträge 34 (1982), 122.

70. Wo einst Erich Ollenhauer stand ...," Die Andere Zeitung (April 4, 1963).

71. Ibid.

72. Letter from Aenne Kolb to Herr Heinzel, May 12, 1964. Letter from Aenne Kolb to the Oberbürgermeister, May 13, 1964, and Letter from the Oberbürgermeister to Aenne Kolb, May 25, 1964. Signatur 977, Magistratsakten III/2-1979, ISG, Frankfurt am Main.

73. Letter from the Stadtkanzlei Hauptamt to the Berufaufbauschule Mittlestufe I und II, November 11, 1963. Signatur 4.461, Magistratsakten 47/49, ISG, Frankfurt am Main.

74. "Magistrats Beschluss Nr. 519: Betr. Überlassung der Paulskirche für eine Veranstaltung der "Kampagne für Abrüstung-Ostermarsche der Atomwaffengegner" am 20.3.1965," Band 2, Akten 1540/6b, Signatur 978, Magistratskten III/2-1979, ISG, Frankfurt am Main.

75. Letter from Mayor Willi Brundert to Klaus Vack, September 22, 1965. Signatur S1/459-4, NL Rudolf Rolfs, ISG, Frankfurt am Main.

76. Ibid. Interestingly, Brundert was also not a Frankfurt native.

77. "Bestimmungen für die Überlassung der Paulskirche zu Frankfurt am Main," September 5, 1966. Blatt 222, Band 1, Akten 1540/b2, Signatur 976, Magistratskten III/2-1979, ISG, Frankfurt am Main.

78. The final draft of the new agreement is dated in pencil as 1966. Correspondence regarding the revisions began in 1964. "Bestimmungen für die Überlassung der Paulskirche zu Frankfurt am Main," September 5, 1966. Blatt 222, Band 1, Akten 1540/b2, Signatur 976, Magistratskten III/2-1979, ISG, Frankfurt am Main. 
79. Ollenhauer to Die Bezirke, March 1, 1961. Mappe 395, NL Ollenhauer, AdsD, Bonn.

80. "30 000 demonstrierten für den Frieden. Ostermarch aus Walldorf, Höchst, Bonames und Offenbach," Frankfurter Allgemeine Zeitung (April 13, 1982). "Nicht auf prominent Redner angewiesen," Frankfurter Allgemeine Zeitung (March 22, 1983). "Ostermarschierer vor dem Römer-Volksfest gegen Aufrüstung und Rechtsradikale,” FNP (March 28, 1988). 